\title{
Levels Politechnic Community Satisfaction to The Use of Lebuhraya Pantai Timur 2
}

\author{
Rosmida binti Ab Ghani ${ }^{1 *}$, Najah binti Mohd Nawi ${ }^{2}$, Norhafiza binti Idris ${ }^{3}$ \\ ${ }^{123}$ Politeknik Sultan Mizan Zainal Abidin \\ $\doteqdot$ e-mail: rosmida5686@gmail.com
}

\begin{abstract}
Construction of East Coast Expressway 2 (LPT2) has a large impact in being able to link the states on the East Coast in a time shorter than existing roads. This gives a more comfortable alternative ride to the local community and beyond. However, there are still complaints from users regarding the facilities and services provided in LPT2. Thus, a study carried out to determine the level of satisfaction of polytechnic communities against the use of LPT2. A total of 222 respondent from four polytechnic involved in this study. Analysis of the findings made by using descriptive statistic and T-test through the software Statistical Package for Social Science (SPSS) version 23. Results of this analysis showed a mean value for items 'security level' in LPT2 is 2.29, i.e. at low mean score. While the 'facilities provided' is 2.50 , where the stage score mean intermediate. Analysis of T-test also found, there is no significant relationship between the levels of satisfaction of users of different gender. Pearson correlation analysis found that the relationship between the usage frequency of LPT2 and the user satisfaction level was weak, but significant. It is hoped that the findings could help provides an overview of the level of satisfaction of the security aspects of polytechnic communities and facilities in LPT2. This can help the parties responsible for providing the best service to oversee and improve LPT2 in all aspects in order to provide optimum satisfaction to the user.
\end{abstract}

Keywords:LPT2, satisfaction level, polytechnic community

\section{Tahap Kepuasan Warga Politeknik Terhadap Penggunaan Lebuhraya Pantai Timur 2}

\begin{abstract}
Pembinaan Lebuhraya Pantai Timur 2 (LPT2) mempunyai kesan yang besar kerana dapat menghubungkan negeri-negeri di Pantai Timur pada masa yang lebih pendek daripada jalan yang ada. Ini memberi laluan alternatif yang lebih selesa kepada masyarakat tempatan dan seterusnya. Walau bagaimanapun, masih ada aduan daripada pengguna mengenai kemudahan dan perkhidmatan yang disediakan di LPT2. Oleh itu, kajian yang dilakukan untuk menentukan tahap kepuasan komuniti politeknik terhadap penggunaan LPT2. Seramai 222 responden daripada empat politeknik terlibat dalam kajian ini. Analisis penemuan yang dilakukan dengan menggunakan statistik deskriptif dan ujian $T$ melalui perisian Statistical Package for Social Science (SPSS) versi 23. Hasil analisis ini menunjukkan nilai min bagi tahap keselamatan item dalam LPT2 ialah 2.29, iaitu pada min yang rendah skor. Sementara 'kemudahan yang disediakan' adalah 2.50, di mana skor tahap bermakna pertengahan. Analisis ujian T juga didapati, tidak terdapat hubungan yang signifikan antara tahap kepuasan pengguna jantina yang berbeza. Analisis korelasi Pearson mendapati bahawa hubungan antara kekerapan penggunaan LPT2 dan
\end{abstract}


tahap kepuasan pengguna adalah lemah, tetapi signifikan. Diharapkan hasil penemuan dapat membantu memberikan gambaran mengenai tahap kepuasan aspek keselamatan masyarakat dan kemudahan politeknik di LPT2. Ini dapat membantu para pihak yang bertanggungjawab menyediakan perkhidmatan terbaik untuk mengawasi dan meningkatkan LPT2 dalam semua aspek untuk memberikan kepuasan yang optimum kepada pengguna.

Keywords:LPT2, Tahap Kepuasan, Warga Politeknik

This is an open access article distributed under the Creative Commons 4.0 Attribution License, which permits unrestricted use, distribution, and reproduction in any medium, provided the original work is properly cited. (C2018 by author

\section{PENGENALAN}

Sebagai sebuah negara yang semakin meningkat maju seharusnya sistem perhubungan yang disediakan mempunyai kecekapan, kemajuan daripada segi perkhidmatan dan teknologi bagi memberi kemudahan dan kepuasan kepada masyarakat. Pelbagai usaha dan strategi baru yang difikirkan oleh kerajaan telah dibuat supaya masalah trafik (kesesakan lalulintas) dapat dikurangkan terutamanya bagi laluan ke negeri-negeri pantai timur disebabkan pertambahan kenderaan saban tahun.

Selari dengan dasar kerajaan untuk mengurangkan kesesakan lalulintas bagi laluan ke pantai timur, pihak kerajaan telah membina Lebuh raya Pantai Timur 1 (LPT1) yang menghubungkan Karak danKuantan,manakala LPT2 yang menghubungkan Jabor danKuala Terengganu sepanjang $184 \mathrm{~km}$ (LPT2, 2018). Kewujudan LPT2 juga memberikan impak kepada masyarakat dengan mempercepatkan pembangunan kawasan sekitar, memendekkan tempoh perjalanan, dan meningkatkan industri pelancongan domestik. Selain itu, ia juga dapat meningkatkan sosio-ekonomi penduduk sekitar dengan mewujudkan peluang pekerjaan dan perniagaan, serta menjadikan kawasan penempatan,perbandaran dan perindustrian yang baru. Pembinaan Lebuhraya Pantai timur memberikan impak yang paling besar dalam menjimatkan masa perjalanan.

\section{Pernyataan Masalah}

Masalah kesesakan lalulintas sentiasa menghantui fikiran masyarakat walaupun pelbagai kemudahan telah disediakan oleh pihak kerajaan. Pertambahan jumlah kenderaan dan pemandu menjadi penyumbang kepada masalah ini. Oleh itu, tahap kepuasan pengguna perlu dipandang serius dalam memastikan pihak konsesi dapat menyediakan perkhidmatan yang efektif kepada pengguna terutamanya daripada aspek keselamatan seperti jalan licin, berlopak, beralun dan binatang berkeliaran di kawasan lebuh raya. Bagi aspek kemudahan pula seperti kawasan rehat dan rawat, stesen minyak, dan plaza tol. Akhbar Berita Harian (2018) melaporkan kemalangan membabitkan mangsa terbabas dan masuk ke dalam gaung akibat cuaca hujan dan jalan yang basah.

Fokus utama kajian ini adalah mengenai perkhidmatan yang disediakan oleh pihak LPT2 daripada aspek keselamatan dan kemudahan. Ianya sering menjadi rungutan kepada penggunaan LPT2 kerana kerap berlaku kemalangan. Sebanyak 339 kemalangan yang berlaku diantara 1 Februari 2015 hingga 2 Jun 2015, 70\% ataupun 238 daripada 339 kemalangan yang berlaku telah disebabkan faktor manusia, 19 peratus atau 65 kes pula adalah akibat haiwan yang menceroboh lebuhraya, dan $11 \%$ atau 36 kes kerana kerosakan kenderaan dan pengairan (Astro Publication, 2015). Oleh itu, penyelidik ingin membuat kajian terhadap penggunaan LPT2 dengan memberi fokus kepada tahap kepuasan pengguna terhadap tahap keselamatan dan kemudahan yang disediakan di LPT2.

\section{Tujuan Kajian}

Kajian ini dijalankan untuk mengenalpasti tahap kepuasan warga politeknik terhadap penggunaan LPT2.

\section{Objektif Kajian}


Objektif kajian ini adalah untuk:

1. Mengenalpasti tahap kepuasan pengguna terhadap tahap keselamatan di LPT2.

2. Mengenalpasti tahap kepuasan pengguna terhadap kemudahan yang disediakan di LPT2.

3. Membandingkan tahap kepuasan penggunaan LPT2 antara jantina.

4. Mengenalpasti perhubungan antara kekerapan penggunaan LPT2 dengan tahap kepuasan pengguna.

\section{Persoalan Kajian}

1. Sejauh manakah tahap kepuasan pengguna terhadap tahap keselamatan di LPT2?

2. Sejauh manakah tahap kepuasan pengguna terhadap kemudahan yang disediakan di LPT2?

3. Adakah terdapat perbezaantahap kepuasan penggunaan LPT2 antara jantina?

4. Adakah terdapat perhubungan antara kekerapan penggunaan LPT2 dengan tahap kepuasan pengguna?

\section{Hipotesis}

$\mathrm{H}_{0-1}$ : Tidak terdapat perbezaan tahap kepuasan penggunaan LPT2 antara jantina.

$\mathrm{H}_{1-1}$ : Terdapat perbezaan tahap kepuasan penggunaan LPT2 antara jantina.

$\mathrm{H}_{0-2}$ : Tidak terdapat hubungan antara kekerapan penggunaan LPT2 dengan tahap kepuasan pengguna.

$\mathrm{H}_{1-2}$ :Terdapat hubungan antara kekerapan penggunaan LPT2 dengan tahap kepuasan pengguna.

\section{Kepentingan Kajian}

Hasil kajian ini diharapkan dapat memberikan input dan membantu pihak pengurusan LPT2 dalam membuat perancangan yang lebih efektif bagi memastikan tahap kepuasan bagi keselamatan dan kemudahan dapat disediakan dengan lebih baik dan berkualiti sejajar dengan keperluan dan kehendak pengguna.

\section{Skop Kajian}

Kajian ini dijalankan untuk mengenalpasti tahap kepuasan pengguna dari segi keselamatan dan kemudahan yang disediakan oleh pihak LPT2. Sampel kajian ini merangkumi kakitangan daripada empat buah politeknik di Negeri Terengganu, iaitu Politeknik Sultan Mizan Zainal Abidin (PSMZA), Politeknik Hulu Terengganu (PHT), Politeknik Kuala Terengganu (PKT) dan Politeknik Besut Terengganu (PBT).

\section{LITERATUR REVIEW}

\section{Perkhidmatan di Lebuh Raya}

Kemudahan infrastruktur pengangkutan memberikan impak yang besar terhadap pembangunan ekonomi negara (Bardi, Attia \& Ustadi, 2000). Pembinaan lebuh raya dilihat bukan sahaja dapat menjimatkan masa perjalanan, malah memberi keselesaan dan menyediakan kemudahan kepada pengguna jalan raya. Pembinaan lebuh raya yang baik pada asasnya adalah mesti memberikan kemudahan jalan bertar yang selamat dan selesa untuk pemanduan. Selain itu, aksesori di sepanjang jalan juga haruslah berfungsi dengan baik. Papan tanda yang disediakan di sepanjang jalan juga harus relevan dalam membantu pengguna sampai ke destinasi yang dituju dengan selamat. Pengguna lebuh raya bertol seharusnya mendapat perkhidmatan yang baik, sesuai dengan standard yang telah ditetapkan (Pancawati, E. \& Kartika, A.G, 2013).

Malaysian Highway Authority (MHA) atau Lembaga Lebuh Raya Malaysia (LLM) merupakan sebuah badan berkanun yang ditubuhkan pada 24 Oktober 1980 dibawah Akta 231 (Perbadanan 1980). LLM pada asalnya berfungsi menyelia dan melaksana rekabentuk, membina, mengawal, mengendali dan 
menyelenggara lebuh raya, mengenakan kutipan tol, membuat kontrak dan peruntukan berkenaan perkara-perkara berkaitan. Walaubagaimanapun selepas Dasar Penswastaan Negara (DSN) diperkenalkan, LLM bertindak menjadi badan yang mengawal selia perkhidmatan syarikat-syarikat konsesi lebuh raya terhadap pengguna jalan raya (LLM, 2018). LPT2 merupakan salah satu lebuh raya yang dikawal selia oleh LLM.

Menurut Šelih, J., Kne, A., Srdić, A., dan Žura, M. (2008), kemudahan infrastruktur di lebuh raya merupakan aset awam yang boleh terdedah kepada kemerosotan nilai dengan bertambahnya masa. Justeru penyelenggaraan perlu sentiasa dilakukan oleh pihak berkenaan mengikut keperluan semasa. Burde, A. (2008) dalam kajiannya menyebut tiga komponen utama dalam perkhidmatan lebuh raya adalah, manusia, peralatan dan komunikasi. Kajian melibatkan pengujian hubungan antara persepsi menyeluruh pengguna lebuh raya terhadap kualiti perkhidmatan penyelenggaraan dan pembolehubah yang dapat mentakrifkan domain kualiti perkhidmatan penyelenggaraan lebuh raya. Proses operasi dan aktiviti penyelenggaraaan boleh dibahagikan kepada tiga kategori iaitu, penyelenggaraan, pembaikan dan penggantian, serta perkhidmatan pelanggan. Penyelenggaraan merujuk kepada kerja-kerja memanjangkan hayat sesuatu kemudahan. Pembaikan dan penggantian pula adalah untuk proses pemulihan sesuatu kemudahan kepada keadaan asal. Manakala perkhidmatan pelanggan pula adalah suatu proses perniagaan yang sistematik untuk memenuhi kehendak pelanggan.Pandangan yang berorientasikan pengguna dapat memberikan maklumat berguna untuk mengetahui sejauhmana sesuatu perkhidmatan berfungsi, dimana perubahan perlu dilakukan, dan samada pengubahsuaian itu memberi perubahan atau tidak, menurut perspektif pengguna. Hasil kajian mendapati dua bahagian perkhidmatan, keselamatan dan kebolehpercayaan memberi hampir separuh varians dalam persepsi keseluruhan kualiti perkhidmatan penyelenggaraan.

\section{Tahap Kepuasan Pengguna}

Kepuasan merujuk kepada Kamus Dewan Edisi Keempat bermaksud perasaan senang hati, lega, selesa dan sejahtera. Dalam Bahasa Inggeris, satisfaction berasal daripada perkataan Latin iaitu satis (cukup) dan farcere (buat). Pengguna pula merujuk kepada orang yang menggunakan sesuatu dan mengambil faedah daripada sesuatu benda (Kamus Dewan, 2018). Kajian oleh Akbar, M., Parvez, N. (2009) mengenalpasti kesan penerimaan perkhidmatan berkualiti, kepercayaan dan kepuasan hati pengguna, terhadap kesetiaan pengguna. Structural Equation Modelling (SEM) telah digunakan untuk menganalisis data. Hasil kajian terbabit mendapati, kepercayaan dan kepuasan pengguna berkadar secara signifikan terhadap kesetiaan pengguna.

Dalam aspek lebuh raya, dua faktor besar yang menyumbang kepada kepuasan pengguna adalah, keadaan jalan yang selamat untuk dilalui dan kemudahan yang disediakan sepanjang perjalanan. Tahap kepuasan pengguna mungkin berbeza dengan jangkaan awal yang dibuat oleh syarikat konsesi lebuh raya, dan mungkin berubah seiring peredaran masa.Menurut Burde, A. (2008), jumlah pengguna lebuh raya yang menyuarakan pandangan terhadap penyelenggaraan lebuh raya telah meningkat. Ini mungkin disebabkan mereka sudah mulai mempunyai ilmu daripada aspek perkhidmatan, daripada keadaan jalan sehinggalah kepada isu persekitaran. Justeru, mengambil kira pandangan pengguna adalah suatu langkah yang bijak dalam menyediakan perkhidmatan lebuh raya yang berkualiti.Bardi, Attia \& Ustadi, (2000) melalui kajiannya untuk mengenalpasti tahap kepuasan pengguna PLUS Expressway Berhad menggunakan model SERVQUAL yang diubahsuai. Pendekatan yang digunakan adalah dengan mencari perbezaan antara jangkaan pengguna terhadap perkhidmatan, dengan apa yang dialami. Penyelidik mendapati pengguna menyenaraikan enam bahagian terbabit paling penting iaitu, keadaan jalan, perkhidmatan PlusRonda, aksesori jalan, pengurusan trafik, penyelenggaraan kemudahan dan kebersihan. Kajian mendapati sekiranya kualiti perkhidmatan mencapai arasjangkaan pengguna, maka kepuasan pengguna akan memberi impak kepada peningkatan hasil ekonomi syarikat.

Wardhana, A. P., Ishibashi, K., \& Kiyota, M. (2011) telah menjalankan kajian untuk mengukur kepuasan pengguna di dua jalan raya utama di Saga, Jepun. Penyelidik menggunakan soalan soal selidik lima skala likert terhadap 2000 pengguna. Soalan soal selidik dibahagikan kepada tiga bahagian utama iaitukemudahan keselamatan jalan, permukaan jalan dan kemudahan stesen di sepanjang jalan. Berdasarkan model regresi, penyelidik mendapati kepuasan pengguna samada secara jarak jauh atau jarak 
dekat, dipengaruhi oleh dua faktor utama iaitu permukaan jalan dan kemudahan jalan. Bagi pengguna jarak jauh, kelancaran permukaan jalan raya paling dipertimbangkan.

\section{METODOLOGI}

\section{Reka Bentuk Kajian}

Metodologi penulisan ini adalah tertumpu kepada aplikasi penyelidikan gaya kuantitatif yang menjurus kepada kaedah tinjauan. Penggunaan teknik tinjauan ini dengan mengimplementasikan teknik soal selidik pada penyelidikan ini adalah berdasarkan kepada rasional (Mohd Majid,2000). Kajian tinjauan digunakan untuk mendapatkan maklumat daripada responden yang ramai iaitu ratusan ataupun ribuan responden (Marican, 2006).

\section{Populasi dan Persampelan}

Responden sasaran kajian ialah warga politeknik daripada empat buah politeknik iaitu Politeknik Sultan Mizan Zainal Abidin (PSMZA), Politeknik Hulu Terengganu (PHT), Politeknik Kuala Terengganu (PKT) dan Politeknik Besut Terengganu (PBT). Kaedah pemilihan sampel dalam kajian ini ialah menggunakan persampelan rawak jenis kelompok berbeza kerana individu sampel tidak terlibat secara langsung. Penyelidik menggunakan pembahagian kawasan atau institusi di mana sampel berada terlebih dahulu(Othman, 2011).Pemilihan ini dilakukan berdasarkan kepada faktor geografi kedudukan keempatempat politeknik ini yang berada paling hampir dengan LPT2. Maka, kebarangkalian warga daripada politeknik ini menggunakan LPT2 dengan kerap adalah lebih tinggi.

Jumlah keseluruhan kakitangan di keempat-empat politeknik adalah dijangkakan sekitar 500 orang. Daripada Jadual Krejcie Morgan, minima sampel yang diperlukan untuk mewakili populasi tersebut adalah seramai 217 orang(Krejcie dan Morgan, 1970). 


\section{Proses Pembentukan Instrumen}

Berikut merupakan prosedur kajian yang dilakukan dalam proses mendapatkan data kajian.

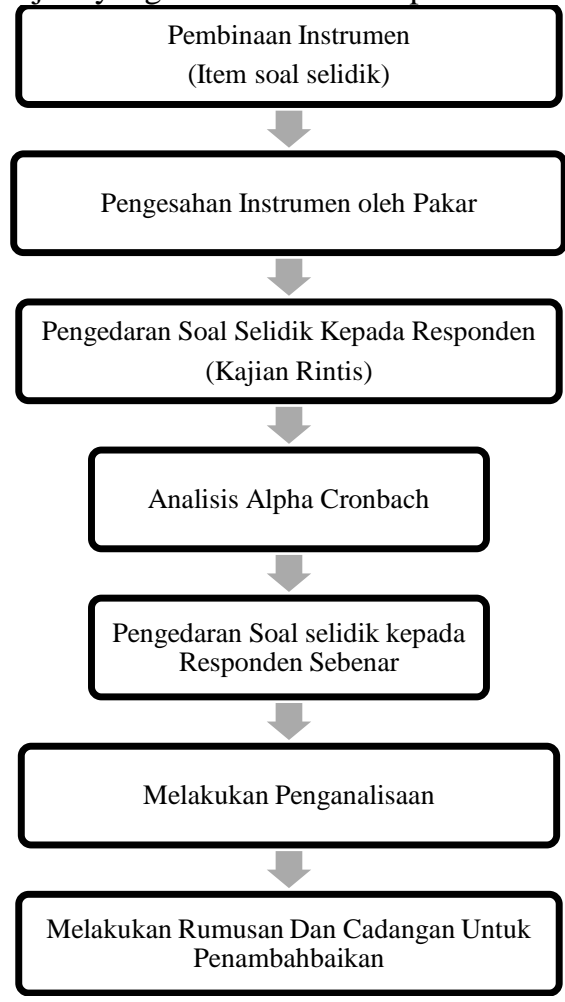

Langkah pertama yang diambil oleh penyelidik untuk memulakan kajian adalah dengan membina instrumen, iaitu item soal selidik. Dalam mengetahui tahap kepuasan pengguna, penyelidik perlu mengenalpasti apakah yang diharapkan oleh pengguna lebuh raya. Selain untuk sampai ke tempat dituju dalam masa yang singkat, pengguna juga perlu sampai dalam keadaan yang selamat dan selesa sepanjang perjalanan.

Oleh itu, penyelidik membahagikan instrumen soal selidik kepada dua sub-bahagian utama iaitu, Bahagian B: Tahap Keselamatan dan Bahagian C: Kemudahan Yang Disediakan. Pada peringkat awal, sejumlah 36 item dibina untuk kedua-dua bahagian. Pembinaan instrumen menggunakan lima skala likert seperti Jadual 1.

\section{Jadual 1: Interpretasi Nilai Skala Likert Bagi Instrumen Kajian}

\begin{tabular}{ccc}
\hline Skala & Nilai & Singkatan \\
\hline 5 & Sangat Setuju & SS \\
4 & Setuju & S \\
3 & Kurang Setuju & KS \\
2 & Tidak Setuju & TS \\
1 & Sangat Tidak Setuju & STS \\
\hline
\end{tabular}

Setelah pembinaan instrumen selesai, semakan dibuat oleh pakar. Menurut Gay dan Air Asian (2003), semakan dan pengesahan daripada pakar amat diperlukan bagi memastikan instrumen kajian itu 
dapat memenuhi kehendak pengkaji berdasarkan kepada objektif kajian yang telah ditetapkan. Bunimin (2016) menegaskan bahawa pemilihan individu sebagai panel pakar adalah bergantung kepada objektif yang dibina sebagai persoalan kajian. Semakan instrumen ini perlu dilakukan bagi memastikan item yang dibina adalah mencukupi dan seimbang. Kesahan instrumen melibatkan kesahan muka, kesahan kandungan dan kesahan konstruk. Penelitian daripada pakar mendapati, untuk Bahagian A, daripada 10 item, 3 item digugurkan kerana kurang relevan dengan tujuan kajian. Untuk Bahagian B pula, 1 item ditambah dan kesemua 15 item dipecahkan kepada sub-bahagian, iaitu jalan raya, aksesori jalan raya dan papan tanda. Untuk Bahagian C, 1 item dikurangkan daripada sejumlah 22 item. Terdapat item yang diperbaiki struktur ayatnya supaya dapat dibaca dengan lebih jelas dan menyampaikan maksud dengan lebih terperinci. Namun dalam masa yang sama dapat difahami dan mudah dijawab oleh responden.

Selepas mendapat persetujuan pakar, instrumen kajian merangkumi tiga aspek iaitu Bahagian A (7 item), Bahagian B (15 item) dan Bahagian C (21 item). Soalan terakhir pada Bahagian C adalah berbentuk soalan terbuka.

Jadual 2: Konstruk Item Soal Selidik

\begin{tabular}{ccc}
\hline Konstruk & Bilangan Item Asal & Bilangan Item \\
\hline Demografi & 10 & 7 \\
Tahap Keselamatan & 14 & 15 \\
Kemudahan Yang Disediakan & 22 & 21 \\
Jumlah Item & 46 & 43 \\
\hline
\end{tabular}

Selepas mendapat kesahan daripada pakar, instrumen kajian diedarkan kepada 31 orang responden untuk kajian rintis. Menurut Krejcie dan Morgan (1970) dan Sekaran (2006), untuk sampel seramai 217 orang, 30 orang adalah memadai untuk mengesahkan kebolehpercayaan item yang dibina. Jadual 3 di atas menunjukkan nilai pekali kebolehpercayaan yang dijadikan penanda aras kepada ujian Alpha Cronbach yang dijalankan oleh penyelidik.

Jadual 3: Interpretasi Nilai Pekali Kebolehpercayaan Alpha Cronbach

\begin{tabular}{cc}
\hline Pekali Kebolehpercayaan & Tahap Kebolehpercayaan \\
\hline 0.90 atau lebih & Amat baik \\
$0.80-0.89$ & Baik \\
$0.60-0.79$ & Sederhana \\
$0.40-0.59$ & Diragui \\
$0.00-0.39$ & Ditolak \\
\hline
\end{tabular}

Selepas kajian rintis dijalankan, analisis mendapati Bahagian B: Tahap Keselamatan memberikan nilai 0.866, manakala Bahagian C: Kemudahan Yang Disediakan pula memberikan nilai yang lebih tinggi iaitu 0.899, seperti yang ditunjukkan dalam Jadual 4. Dengan itu, kesimpulan dapat dibuat bahawa item yang dibina adalah pada tahap baik, iaitu antara 0.80 sehingga 0.89 .

Jadual 4: Indeks Kebolehpercayaan Alpha Cronbach Bagi Setiap Bahagian Dalam Instrumen

Kajian

\begin{tabular}{lcc}
\hline \multicolumn{1}{c}{ Bahagian } & Bilangan Item & Alpha Cronbach \\
\hline Tahap Keselamatan & 15 & 0.866 \\
Kemudahan Yang Disediakan & 20 & 0.899 \\
\hline
\end{tabular}

Pengumpulan Data 
Instrumen kajian yang digunakan untuk mengumpul data adalah dengan menggunakan set soalan soal selidik. Menurut Hopes, C., Kramer, J., Williams, K. (2006), pertemuan dengan responden adalah lebih efektif berbanding meminta mereka untuk datang kepada anda. Justeru soalan soal selidik terbabit diedarkan kepada 222responden daripada empat buah politeknik. Pengedaran ini dijalankan dalam tempoh masa tertentu secara terus kepada pengguna. Maklum balas daripada responden merupakan data primer kepada kajian ini.

\section{Analisis Data}

Ujian statistik yang dijalankan untuk analisis keputusan kajian ini adalah dengan menggunakan analisis deskriptif dengan mencari nilai frekuensi, min dan sisihan piawai. Ujian-t turut dilakukan untuk mengetahui samada terdapat perbezaan tahap kepuasan antara pengguna lelaki dan perempuan di LPT2. Selain itu, korelasi Pearson turut dilakukan untuk mengetahui adakah terdapat perhubungan antara kekerapan penggunaan LPT2 dengan tahap kepuasan pengguna. Data dianalisis menggunakan Perisian SPSS versi 23.

Jadual 5 menunjukkan tahap penerimaan skor min yang dibina oleh Mohamed Najib (1999) yang digunakan untuk dijadikan panduan dalam kajian ini.

\section{Jadual 5:Tahap Penerimaan Skor Min}

\begin{tabular}{cc}
\hline Julat Skor Min & Tahap Nilai Skor Min \\
\hline $1.00-1.49$ & Amat Rendah \\
$1.50-2.49$ & Rendah \\
$2.50-3.49$ & Sederhana \\
$3.50-4.49$ & Tinggi \\
$4.50-5.00$ & Amat Tinggi \\
\hline
\end{tabular}

\section{DAPATAN KAJIAN DAN PERBINCANGAN}

\section{Responden Kajian}

Jadual 6 menunjukkan latar belakang responden kajian mengikut jantina. Hasil kajian mendapati, daripada 222 orang responden, $28.8 \%$ iaitu 64 orang adalah lelaki, manakala $71.2 \%$ iaitu 158 orang adalah perempuan.

Jadual 6: Latar Belakang Responden Mengikut Jantina

\begin{tabular}{cccc}
\hline No & Jantina & Bilangan & Peratusan (\%) \\
\hline 1 & Lelaki & 64 & 28.8 \\
2 & Perempuan & 158 & 71.2 \\
& Jumlah & $\mathbf{2 2 2}$ & $\mathbf{1 0 0}$ \\
\hline
\end{tabular}

Jadual 7 pula menunjukkan bilangan responden mengikut politeknik. Seramai 163 orang, iaitu 73.4\% adalah daripada PSMZA, manakala 20 orang iaitu 9.0\% daripada PHT dan PKT, dan 19 orang iaitu $8.6 \%$ adalah daripada PBT. Peratusan ini dipengaruhi oleh bilangan populasi di sesebuah politeknik. Peratusan paling tinggi adalah sampel daripada PSMZA kerana bilangan keseluruhan populasi di PSMZA mencecah 319 orang, berbanding politeknik lain sekitar 28 ke 78 orang sahaja.

\section{Jadual 7: Latarbelakang Responden Mengikut Politeknik}




\begin{tabular}{cccc}
\hline No & Politeknik & Bilangan & Peratusan (\%) \\
\hline 1 & PSMZA & 163 & 73.4 \\
2 & PHT & 20 & 9.0 \\
3 & PKT & 20 & 9.0 \\
4 & PBT & 19 & 8.6 \\
& Jumlah & $\mathbf{2 2 2}$ & $\mathbf{1 0 0}$ \\
\hline
\end{tabular}

Jadual 8 menunjukkan latar belakang responden mengikut kekerapan perjalanan pengguna. Hasil kajian mendapati seramai enam orang, iaitu 2.7\% responden sahaja menggunakan LPT2 setiap hari, 31 orang, iaitu $14.0 \%$ menggunakan setiap minggu, 86 orang, iaitu 38.7\% menggunakan sebanyak 7-12 kali setahun, manakala 99 orang, iaitu $44.6 \%$ yang lain sebanyak 1-6 kali sahaja dalam setahun.

Jadual 8: Latarbelakang Responden Mengikut Kekerapan Perjalanan Pengguna

\begin{tabular}{cccc}
\hline No & Kekerapan Perjalanan & Bilangan & Peratusan (\%) \\
\hline 1 & Setiap Hari & 6 & 2.7 \\
2 & Setiap Minggu & 31 & 14.0 \\
3 & 7-12 kali setahun & 86 & 38.7 \\
4 & $1-6$ kali setahun & 99 & 44.6 \\
& Jumlah & $\mathbf{2 2 2}$ & $\mathbf{1 0 0}$ \\
\hline
\end{tabular}

\section{Persoalan Kajian 1:Apakah tahap kepuasan pengguna terhadap keselamatan di LPT2?}

Jadual 9 menunjukkan tahap kepuasan pengguna terhadap tahap keselamatan di LPT2. Keputusan mendapati, untuk item jalan raya, nilai min yang diperolehi adalah 2.01 dengan sisihan piawai 0.609. Untuk item aksesori jalan raya pula, nilai min adalah 2.35 dengan sisihan piawai 0.564. Manakala untuk item papan tanda, nilai min adalah 2.50 dengan sisihan piawai 0.561.Berdasarkan jadual tahap penerimaan skor, nilai min untuk jalan raya dan aksesori jalan raya berada pada tahap rendah, manakala untuk papan tanda berada pada tahap sederhana. Nilai ini menunjukkan tahap nilai skor min adalah rendah dengan nilai keseluruhan 2.29.

Jadual 9: Tahap Kepuasan Pengguna Terhadap Tahap Keselamatan di LPT2

\begin{tabular}{cccc}
\hline No & Item & Min & Sisihan Piawai \\
\hline B1 & Jalan Raya & 2.01 & 0.609 \\
B2 & Aksesori Jalan Raya & 2.35 & 0.564 \\
B3 & Papan Tanda & 2.50 & 0.561 \\
& Min Keseluruhan & $\mathbf{2 . 2 9}$ & \\
\hline
\end{tabular}

Persoalan Kajian 2: Apakah tahap kepuasan pengguna terhadap kemudahan yang disediakan di LPT2?

Jadual 10 menunjukkan tahap kepuasan pengguna terhadap kemudahan yang disediakan di LPT2. Seperti yang dapat dilihat, nilai min untuk item surau adalah 2.72 dengan sisihan piawai 0.469 . Nilai min untuk item tandas pula adalah 2.48 dengan sisihan piawai 0.544 . Untuk item R\&R, nilai min adalah 2.18 dengan sisihan piawai 0.695. Kemudahan OKU mempunyai min 2.63 dengan sisihan piawai 0.578. Plaza tol pula memberi nilai min 2.50 dengan sisihan piawai 0.615 . Berdasarkan jadual tahap penerimaan skor, nilai min untuk item tandas dan R\&R berada di tahap rendah, manakala item surau, kemudahan OKU dan plaza tol berada di tahap sederhana.Nilai min keseluruhan bahagian ini adalah 2.50 , berada pada tahap skor min sederhana. 
Jadual 10: Tahap Kepuasan Pengguna Terhadap Kemudahan Yang Disediakan di LPT2

\begin{tabular}{lccc}
\hline No & Item & Min & Sisihan Piawai \\
\hline C1 & Surau & 2.72 & 0.469 \\
C2 & Tandas & 2.48 & 0.544 \\
C3 & R\&R & 2.18 & 0.695 \\
C4 & Kemudahan OKU & 2.63 & 0.578 \\
C5 & Plaza Tol & 2.50 & 0.615 \\
& Min Keseluruhan & $\mathbf{2 . 5 0}$ & \\
\hline
\end{tabular}

Persoalan Kajian 3: Adakah Terdapat Perbezaan Tahap Kepuasan Penggunaan LPT2 Antara Jantina?

Jadual 11 menunjukkan perbezaan tahap kepuasan terhadap tahap keselamatan di LPT antara lelaki dan perempuan. Didapati, nilai ( $\mathrm{t}=-1.853), \mathrm{p}>0.05$ (0.090) untuk jalan raya, manakala untuk aksesori jalan raya, nilai $(\mathrm{t}=-2.444), \mathrm{p}>0.05(0.083)$. Untuk papan tanda pula, nilai $(\mathrm{t}=-0.604), \mathrm{p}>0.05(0.083)$. Dengan ini kesemua item bagi tahap keselamatan di LPT2 memberikan nilai $p>0.05$. Justeru dapat dibuat kesimpulan bahawa tidak terdapat perbezaan yang signifikan untuk kesemua item. Lelaki dan perempuan mempunyai pandangan yang sama terhadap tahap keselamatan di LPT2. Maka Ho diterima.

Jadual 11: Ujian-T Perbezaan Tahap Kepuasan Terhadap Tahap Keselamatan di LPT2 Antara

\begin{tabular}{|c|c|c|c|c|c|c|c|}
\hline Item & Jantina & $\mathbf{N}$ & Min & $\begin{array}{l}\text { Sisihan } \\
\text { Piawai }\end{array}$ & $\bar{t}$ & df & Sig. (2-tailed) \\
\hline \multirow[t]{2}{*}{ Jalan Raya } & Lelaki & 64 & 1.89 & 0.645 & \multirow{2}{*}{-1.853} & \multirow{2}{*}{220} & \multirow{2}{*}{0.090} \\
\hline & Perempuan & 158 & 2.06 & 0.589 & & & \\
\hline \multirow{3}{*}{$\begin{array}{c}\text { Aksesori Jalan } \\
\text { Raya }\end{array}$} & Lelaki & 64 & 2.20 & 0.596 & \multirow{3}{*}{-2.444} & \multirow{3}{*}{220} & \multirow{3}{*}{0.083} \\
\hline & & & & & & & \\
\hline & Perempuan & 158 & 2.41 & 0.542 & & & \\
\hline \multirow[t]{2}{*}{ Papan Tanda } & Lelaki & 64 & 2.47 & 0.642 & \multirow{2}{*}{-0.604} & \multirow{2}{*}{220} & \multirow{2}{*}{0.083} \\
\hline & Perempuan & 158 & 2.52 & 0.526 & & & \\
\hline
\end{tabular}

Jadual 12 menunjukkan perbezaan tahap kepuasan terhadap kemudahan yang disediakan di LPT antara lelaki dan perempuan. Didapati, nilai $(\mathrm{t}=-0.670), \mathrm{p}>0.05(0.503)$ untuk surau, manakala untuk tandas, nilai ( $\mathrm{t}=0.858), \mathrm{p}>0.05$ (0. 392). Untuk $\mathrm{R} \& \mathrm{R}$ pula, nilai ( $\mathrm{t}=-1.611), \mathrm{p}>0.05$ (0.109). Kemudahan OKU mencatatkan nilai ( $\mathrm{t}=-0.092), \mathrm{p}>0.05$ (0.927), dan yang terakhir untuk plaza tol, nilai $(\mathrm{t}=-1.624)$, $\mathrm{p}>0.05$ (0.106). Dengan ini kesemua item bagi kemudahan yang disediakan di LPT2 memberikan nilai $\mathrm{p}>0.05$. Justeru dapat dibuat kesimpulan bahawa tidak terdapat perbezaan yang signifikan untuk kesemua item. Lelaki dan perempuan mempunyai pandangan yang sama terhadap kemudahan yang disediakan di LPT2. Maka H0-1 diterima.

Jadual 12: Ujian-T Perbezaan Tahap Kepuasan Terhadap Kemudahan Yang Disediakan di LPT2

\begin{tabular}{|c|c|c|c|c|c|c|c|}
\hline \multicolumn{8}{|c|}{ Antara Jantina } \\
\hline Item & Jantina & $\mathbf{N}$ & Min & $\begin{array}{l}\text { Sisihan } \\
\text { Piawai }\end{array}$ & $\mathbf{t}$ & df & $\begin{array}{l}\text { Sig. (2- } \\
\text { tailed) }\end{array}$ \\
\hline Surau & $\begin{array}{c}\text { Lelaki } \\
\text { Perempuan }\end{array}$ & $\begin{array}{c}64 \\
158\end{array}$ & $\begin{array}{l}2.69 \\
2.73\end{array}$ & $\begin{array}{l}0.500 \\
0.457\end{array}$ & -0.670 & 220 & 0.503 \\
\hline
\end{tabular}




\begin{tabular}{cccccccc} 
Tandas & Lelaki & 64 & 2.53 & 0.563 & 0.858 & 220 & 0.392 \\
& Perempuan & 158 & 2.46 & 0.537 & & & \\
R\&R & Lelaki & 64 & 2.06 & 0.664 & -1.611 & 220 & 0.109 \\
& Perempuan & 158 & 2.23 & 0.704 & & & \\
Kemudahan & Lelaki & 64 & 2.63 & 0.604 & & & 0.927 \\
OKU & & & & & -0.092 & 220 & \\
& Perempuan & 158 & 2.63 & 0.568 & & & \\
Plaza Tol & Lelaki & 64 & 2.39 & 0.657 & -1.624 & 220 & 0.106 \\
& Perempuan & 158 & 2.54 & 0.593 & & & \\
\hline
\end{tabular}

\section{Persoalan Kajian 4: Adakah terdapat perhubungan antara kekerapan penggunaan LPT2 dengan tahap kepuasan pengguna?}

Jadual 13 menunjukkan, pada tahap kepercayaan 95\%,nilai pekali korelasi antara kekerapan penggunaan LPT2 dengan tahap kepuasan pengguna adalah $\mathrm{r}(220)=0.169, \mathrm{p}=0.012$. Justeru kesimpulan dapat dibuat bahawa hubungan antara dua pembolehubah adalah sederhana lemah (Mohd Lazim, A., \& Wan Muhamad Amir, W. A., 2013). Dengan nilai p $<0.05$, didapati terdapat hubungan yang signifikan antara kekerapan pengguna menggunakan LPT2 dengan tahap kepuasan mereka terhadap perkhidmatan di LPT2. Maka H0-2 ditolak.

Jadual 13: Korelasi antara kekerapan menggunakan LPT2 dengan tahap kepuasan

\begin{tabular}{ccccc}
\hline & Min & Sisihan Piawai & Pekali Korelasi & Sig. (2-tailed) \\
\hline Kekerapan Perjalanan & 3.2500 & 0.796 & 0.169 & 0.012 \\
Tahap Kepuasan & 2.4212 & 0.39293 & & \multirow{2}{*}{. }
\end{tabular}

*korelasi signifikan pada aras 0.05 (2-tailed)

\section{Perbincangan Hasil Kajian}

Berdasarkan analisis yang telah dijalankan, seramai 222 orang responden telah menjawab soalan soal selidik yang diedarkan, dimana 64 daripadanya adalah lelaki manakala 158 yang lain adalah perempuan. Daripada angka tersebut, 163 orang adalah daripada PSMZA, 20 orang daripada PHT dan PKT, manakala selebihnya 19 orang daripada PBT. Antara faktor demografi yang turut diambilkira adalah kekerapan responden menggunakan LPT2. Didapati hanya enam orang sahaja menggunakan LPT2 setiap hari, 31 orang menggunakan setiap minggu, 86 orang menggunakan sebanyak 7-12 kali setahun, manakala 99 orang yang lain sebanyak 1-6 kali sahaja dalam setahun.

Bagi menjawab persoalan kajian pertama, tahap kepuasan pengguna terhadap tahap keselamatan di LPT2 adalah antara 2.01 hingga 2.50 dengan nilai min 2.29. Nilai min terendah dicatatkan untuk item jalan raya. Ini menunjukkan kepuasan pengguna terhadap keadaan jalan raya berada pada tahap rendah sahaja. Analisis mengikut soalan mendapati, pengguna amat tidak bersetuju dengan item yang mengatakan jalan raya di LPT2 tidak beralun. Terdapat banyak lubang yang terbentuk di atas jalan (Utusan Online, 2015). Selain itu, mungkin isu binatang liar yang berkeliaran di kawasan lebuh raya turut menjadi penyebab. Ini seperti dilaporkan oleh Sinar Harian (2016) seekor harimau belang telah mati dirempuh sebuah kenderaan di kilometre 321.2 berhampiran Plaza Tol Kerteh. Tapir juga turut dilaporkan berkeliaran menghalang laluan kenderaan di LPT2 (Sinar Harian, 2017).

Untuk persoalan kajian yang kedua pula, tahap kepuasan pengguna terhadap kemudahan yang disediakan di LPT2 berada pada tahap sederhana dengan nilai min antara 2.18 hingga 2.72, memberikan nilai min keseluruhan 2.50. Pengguna kelihatan paling tidak berpuashati dengan tahap kemudahan di R\&R.Analisis mengikut soalan mendapati nilai min untuk stesen minyak yang disediakan di LPT2 
mendapat nilai min terendah. Ini adalah kerana, tiada stesen minyak disediakan di sepanjang lebuh raya sepanjang $184 \mathrm{~km}$ ini (Utusan Online, 2015).

Keputusan ini masih jauh berbanding tahap kepuasan pengguna jalan raya dalam kajian Wardhana, A. P., Ishibashi, K., \& Kiyota, M. (2011) yang mendapat nilai min 3.05 untuk item kemudahan keselamatan jalan, 3.17 untuk permukaan jalan dan 3.27 untuk kemudahan stesen yang ada di sepanjang jalan. Namun begitu menurutElvik, R. (2010), masalah keselamatan jalan raya merupakan masalah global yang sukar diselesaikan dan mengambil masa yang lama serta merisikokan ramai pengguna dengan kemalangan.

Menjawab persoalan kajian yang ketiga, analisis menunjukkan tidak terdapat perbezaan antara tahap kepuasan penggunaan LPT2 antara lelaki dan perempuan. Ini dapat dilihat apabila nilai p untuk kesemua item keselamatan di LPT2 dengan item kemudahan yang disediakan di LPT2 menunjukkan nilai melebihi 0.05. Justeru kesimpulan dapat dibuat bahawa kepuasan penggunaan LPT2 tidak dipengaruhi oleh jantina.

Ujian Korelasi Pearson turut dilakukan bagi menjawab persoalan kajian yang keempat. Analisis mendapati, terdapat hubungan sederhana lemah antara kekerapan penggunaan LPT2 dengan tahap kepuasan pengguna. Meskipun begitu, dengan nilai $\mathrm{p}<0.05$, hubungan antara dua pembolehubah ini adalah signifikan.Dapat disimpulkan bahawa kekerapan penggunaan LPT2 mempunyai perhubungan dengan tahap kepuasan pengguna LPT2.

\section{KESIMPULAN}

\section{Cadangan}

Berdasarkan keputusan yang diperolehi daripada kajian ini, penyelidik mendapati tahap kepuasan pengguna yang terdiri daripada warga politeknik adalah berada pada tahap di bawah sederhana. Keduadua item yang dinilai daripada instrumen kajian iaitu tahap keselamatan dan kemudahan yang disediakan di LPT2 masing-masing memberikan min keseluruhan 2.29 dan 2.50. Ini menunjukkan pengguna daripada keempat-empat politeknik merasakan perkhidmatan yang disediakan oleh pihak konsesi LPT2 belum mencapai tahap yang memuaskan. Justeru cadangan perlu diunjurkan kepada pemilik konsesi LPT2 iaitu Lebuhraya Pantai Timur 2 Sdn Bhd untuk meningkatkan tahap perkhidmatan di LPT2. Responden turut memberikan cadangan pada ruangan soalan terbuka dalam instrumen kajian. Antara perkara yang perlu diberi perhatian oleh pihak konsesi ialah:

1. Masalah jalan beralun yang boleh menyebabkan risiko kemalangan terutamanya apabila pengguna melaluinya pada waktu malam dengan cuaca hujan.

2. Penyelenggaran jalan dilakukan dengan teliti dan berkala.

3. Reflective lamp sentiasa dipastikan berfungsi dengan baik.

4. Memastikan garisan putih pembahagi jalan dapat dilihat dengan jelas terutamanya pada waktu malam dengan cuaca hujan.

5. Memeriksa pencahayaan di flyoverberfungsi dengan baik.

6. Memperbanyakkan papan tanda peringatan had laju, agar pengguna peka terhadap had yang ditetapkan.

7. Pagar dipastikan sentiasa bertutup untuk mengelakkan binatang liar berkeliaran dan mendatangkan risiko kepada pengguna.

8. Mewujudkan stesen minyak dengan kadar segera.

9. Kadar bayaran tol yang dikenakan sepatutnya lebih rendah setanding dengan kualiti perkhidmatan yang disediakan.

10. Meningkatkan tahap keselamatan di R\&R.

11. Menambahkan lorong untuk bayaran tol bagi mengelakkan kesesakan jalan raya pada waktuwaktu puncak. 
Beberapa batasan kajian dapat dilihat dalam kajian ini. Pertama, kajian ini memberi fokus kepada pengguna warga politeknik di empat buah institusi sahaja. Kajian pada masa hadapan mungkin boleh meluaskan populasi responden kepada orang awam yang bertugas di sektor awam dan swasta sekitar negeri Terengganu, untuk melihat adakah institusi memainkan peranan dalam mempengaruhi tahap kepuasan penggunaan LPT2. Selain itu, kajian mungkin boleh diperluaskan kepada warga politeknik di negeri-negeri pantai timur iaitu Kelantan dan Pahang. Kedua, kajian ini merupakan kajian kuantitatif menggunakan instrumen soal selidik. Mungkin kajian yang seterusnya boleh dilakukan secara kualitatif menggunakan kaedah temubual. Ini dapat membantu penyelidik mengetahui dengan lebih terperinci kehendak pengguna di LPT2. Ketiga, analisis yang dijalankan adalah dengan mencari min, sisihan piawai, perbandingan Ujian-T dan korelasi Pearson sahaja antara pembolehubah. Mungkin lebih banyak analisis dapat dilakukan oleh penyelidik pada masa akan datang.

\section{Rumusan}

LPT2 merupakan sebuah projek berskala besar yang telah menimbulkan pelbagai kontroversi sejak awal pembinaan sehinggalah apabila dibuka kepada umum. Meskipun projek ini memberi manfaat kepada ramai orang awam terutamanya penduduk negeri Terengganu, pelbagai kesan buruk turut diperkatakan. Justeru kajian ini dijalankan bertujuan untuk mengetahui sejauhmanakah pengguna berpuashati dengan perkhidmatan di LPT2 ini. Kajian yang dijalankan di empat buah politeknik di Terengganu mendapati perkhidmatan di LPT2 masih jauh daripada standard yang dijangkakan oleh pengguna. Ini merupakan suatu penemuan yang mengejutkan kerana responden secara majoriti bersetuju bahawa masih terlalu banyak ruang penambahbaikan yang boleh dilakukan oleh pihak konsesi LPT2. Kedua-dua item utama dalam kajian ini berada pada tahap bawah sederhana menurut pandangan responden. Item yang memberi nilai min paling rendah adalah tahap keselamatan di LPT2. Manakala Ujian-T bagi mengenalpasti kewujudan perbezaan tahap kepuasan antara jantina pula mendapati tiada perbezaan yang signifikan. Ujian korelasi Pearson pula mendapati terdapat hubungan yang signifikan antarakadar kekerapan penggunaan LPT2 dengan tahap kepuasan pengguna tetapi sederhana lemah.

Hasil kajian ini diharapkan dapat menjadi suara kecil yang didengari oleh pihak-pihak berkenaan dalam usaha meningkatkan mutu perkhidmatan di LPT2. Usaha ini penting untuk menjamin keselamatan orang awam dalam memastikan tiada nyawa yang terkorban atas kelalaian dan ketidakcekapan orang lain.

\section{DAFTAR PUSTAKA}

Ahmad, A., \& Jinggan, N. (2017). Pengaruh kompetensi kemahiran guru dalam pengajaran terhadap pencapaian akademik pelajar dalam mata pelajaran Sejarah. JuKu: Jurnal Kurikulum \& Pengajaran Asia Pasifik, 3(2), 1-11.

Akbar, M. M., \& Parvez, N. (2009). Impact of service quality, trust, and customer satisfaction on customers loyalty. ABAC Journal, 29(1).

Anton A. L. and L. G. Perouhoff (2002). Customer Relationship Management. Prentice Hall

Astro Publication (2015, Jun 23). Majoritit kemalangan di LPT2 disebabkan faktor manusia-Lembaga Lebuhraya Malaysia. Didapati daripada: http://drebar.astroawani.com/detail/majoriti-kemalangandi-lpt2-disebabkan-faktor-manusia-lembaga-lebuhraya-malaysia-64459

Basri, Mat Sanusi (2008) Customer satisfaction: A study on highway service provider. Masters thesis, University of Malaya.

Berita Harian (2018, Mei 28). Seorang maut, dua parah kenderaan masuk gaung. Retrieved on 28 Mei 2018 from https://www.bharian.com.my/berita/kes/2018/03/403259/seorang-mautdua-parah-kenderaan-masuk-gaung

Bunimin, J. (2016). Model konsep pembangunan profesionalisme tenaga pengajar kolej vokasional Malaysia(Doctoral dissertation, Universiti Tun Hussein Onn Malaysia).

Burde, A. (2008). A study on road users' overall perceptions of highway maintenance service quality and the variables that define the highway maintenance service quality domain(Doctoral dissertation, Virginia Tech). 
Elvik, R. (2010). Why some road safety problems are more difficult to solve than others. Accident Analysis \& Prevention, 42(4), 1089-1096.

Gay, L. R. dan Airasian, P. (2003). Educational research: Competencies for analysis and applications (7th ed.). Ohio: Merrill Prentice Hall.

Ghafar, MN. (1999). Penyelidikan Pendidikan. Skudai: Universiti Teknologi Malaysia.

Hopes, C., Kramer, J., Williams, K., (2006), Public Involvement Practices and Perspectives of Florida's Metropolitan Planning Organizations, Transportation Research Record No. 1981, 100- 108, Washington, D.C.

Kamus Dewan Keempat (2018). Didapati daripada: http://prpm.dbp.gov.my/cari1 ?keyword=kepuasan.

Krejcie R.V., \& Morgan D.W. (1970). Determining sample size for research activities.Educational and Psychological Measurement 30, 607-610.

Marican, S. (2006). Penyelidikan sains sosial: Pendekatan pragmatik. Edusystem.

Mat, N., \& Boon, Y. (2010). Tahap Kepuasan Pelajar Terhadap Pengurusan Asrama Di kolej 9 Universiti Teknologi Malaysia Skudai, Johor (Doctoral dissertation, Universiti Teknologi Malaysia).

Mohd Lazim, A., \& Wan Muhamad Amir, W. A. (2013). Analisis Data Dengan Statistik Asas. Kuala Terengganu, Terengganu, Malaysia: Penerbit UMT.

Mohd Majid, K. (2000). Kaedah penyelidikan pendidikan. Dewan Bahasa dan Pustaka. Kuala Lumpur.

Nurul Zaihah (2017, Januari 15) Selepas Pak Belang, Tapir pula Dijumpai di LPT2. Sinar Harian. Didapati pada April 20 fromhttp://www.sinarharian.com.my/edisi/terengganu/selepaspak-belang-tapir-pula-dijumpai-di-lpt2-1.625940

Pancawati, E., \& Kartika, A. G. (2013). Analisis Layanan Jalan Tol Berdasarkan Kebutuhan Pengguna (Studi Kasus Ruas Jalan Tol Surabaya-Gresik). In Prosiding Seminar Nasional Manajemen Teknologi XIX.

Portal Rasmi Lembaga Lebuh Raya Malaysia (2018). Didapati daripada: http://www.Ilm.gov.my/corporate_info

Portal Rasmi Lebuhraya Pantai Timur 2 (2018). Didapati daripada: www.lpt2.com.my/about.html

Ramli, N., Run, C. S., \& Idris, F. (2009). Kajian Kepuasan Pelanggan Perpustakaan Universiti Awam di Malaysia. Jurnal Pengurusan (UKM Journal of Management), 28.

Šelih, J., Kne, A., Srdić, A., \& Žura, M. (2008). Multiple- criteria decision support system in highway infrastructure management. Transport, 23(4), 299-305.

Udo, G. J., Bagchi, K. K., \& Kirs, P. J. (2010). An assessment of customers'e-service quality perception, satisfaction and intention. International Journal of Information Management, 30(6), 481-492.

Utusan Online (2015). LPT 2 masih banyak perlu diperbaiki. Retrieved on 24 Mei 2017 fromhttp://m.utusan.com.my/rencana/forum/Ipt2-masih-banyak-perlu-diperbaiki1.85325

Wardhana, A. P., Ishibashi, K., \& Kiyota, M. (2011). Consideration of Road Management from the View Points of Long-and Short-Distance Road User's Satisfaction. Civil Engineering Dimension, 13(2), 90-97. 